\title{
CAN INVESTMENT INCENTIVES CAUSE UNEMPLOYMENT? AN EMPIRICAL ANALYSIS OF THE RELATIONSHIP BETWEEN FDI AND EMPLOYMENT BASED ON THE OLI FRAMEWORK
}

\author{
Evan, T., Bolotov, I.
}

Tomáš Evan / Czech Technical University, Faculty of Information Technology, Department of Software Engineering, Thákurova 9, 16000 Prague 6. The Czech Republic; University of New York in Prague, School of Business, Londýnská 41, 12000 Prague, The Czech Republic. Email: tomas.evan@fit.cvut.cz llya Bolotov / Prague University of Economics and Business, Faculty of International Relation, Department of International Economic Relations, Winston Churchill sq. 4, 13067 Praha 3 - Žižkov, Prague, Czech Republic. Email: ilya.bolotov@vse.cz

\begin{abstract}
Particularly in depressed regions, politicians often use unemployment as the main argument for investment incentives provided to MNCs. This paper applies Dunning's OLI Framework to the relationship between FDI and employment, assuming that political negotiation between MNCs and the host government might have a zero or negative effect on employment. Since the last letter of OLI, internalisation, suggests that MNCs optimise all production factors available to them and "subsidies" provided to MNCs by governments decrease the relative price of capital, MNCs may use more labour-saving techniques. Two hypotheses are tested using the dynamic panel model (DPD) and Granger causality tests for 193 countries from 1985-2019, where the first is supported with no strong relationship between the variables.

Implications for Central European audience: The paper results suggest the importance of a critical debate on the efficiency of investment incentives. This paper is among the first trying to disentangle the rather complex issue of FDI and employment on a theoretical and econometric level.
\end{abstract}

Keywords: foreign direct investment; unemployment; OLI; panel data JEL Classification: C23, E24, F21

\section{Introduction}

Many reasons are claimed for why governments attract foreign direct investment (FDI) with their financial subsidies. Arguably the most notable among these is the increase of employment in technologically advanced industries, often in underdeveloped regions of the host country (please consult i.a. Golejewska, 2002; Karlsson \& Norden, 2007; Rizvi \& Nishat, 2009; Tambunan, 2011). Theoretical concepts, namely Dunning's eclectic model of international production and his OLI paradigm, helped us identify at least three problems related to this reasoning. These were, (i) many Multinational Corporations (MNCs) enter the 
new market with the express purpose of increasing efficiency and cutting costs, including labour costs; (ii) governmental subsidies guarantee redirection of FDI from the most suitable investment location to that where the sum of income for MNCs is the largest at the expense of world production and employment; (iii) relative price of capital will decrease in comparison with the relative price of labour due to the financial subsidies given and MNCs will be motivated to use more labour-saving techniques in their worldwide FDI.

So, it is clear that the government will negotiate the extra employment for its subsidy, yet, it is possible that another investment in another, perhaps more suitable, location will not take place, or the level of employment there will be suppressed. It is also conceivable to deduce that the most easily substituted, or low-skilled, labour force will suffer from above market level unemployment, paid for by its taxes. Therefore, this paper aims to methodologically explain and empirically test two hypotheses under which FDI may cause no rise in employment or even increase unemployment, i.e. the negative substitution effect of a capital price decrease. We employ Dunning's OLI Framework (and related research), mainstream economic modelling, and a dynamic panel model (DPD) on variables in absolute and relative terms on a strongly balanced dataset of 193 countries over the years 1985-2019 (35 years), also distinguishing between the stated FDI origin (OECD and the rest of the world) to account for the different potential treatment of investors.

\section{Literature Review}

The alleged main reasons governments attract foreign direct investment (FDI) are interlinked improvements of the balance of payments, technology transfer, increased economic growth and employment in depressed areas, and a shortage of capital. These reasons have been tested in recent years, and many, if not all, found problematic, possibly non-existent. We will focus on literature concentrated on the link between FDI and employment, yet other issues are also mentioned.

A significant amount of research about the impact of FDI inflow on employment relates to Central and Eastern Europe, particularly for the transformation period (Braconier \& Ekholm, 2002; Cristescu et al., 2015; Hunya \& Geishecker , 2005; Lipsey, 2006; Radosevic et al., 2003; Zemplinerova, 2012; i.a.). Estrin (2017) finds a break in the trend in 2008, as the relationship between FDI and output and GDP was strongly correlated until the financial crisis, but far less afterwards. Like many others before him, he suggests that employment, however, was inversely correlated because FDI inflow caused efficiency-seeking restructuring, particularly due to MNCs' acquisitions through the privatisation process. While FDI inflow brought about access to advanced technology, new skills and management techniques, among other benefits in Central Europe, it also caused more restructuring than other types of privatisation, with an adverse effect on the labour market.

Ernst (2005) reports that Brazil and Argentina have experienced no increase in employment as their FDI mainly came in the form of M\&As or as a result of privatisation of public utility companies or bank restructuring. This meant more efficient usage of existing productive assets instead of establishing new ones. De Castro et al. (2013) suggests Brazil FDI was market-seeking, while the proximity of Mexico to the United States attracted efficiencyseeking MNCs. Mexico experienced a surge, helped by FDI, in manufacturing employment in the 1990s, but this was attributable to the maquiladora industry with limited technology transfer due to the high import content of exports and labour cost comparative advantage 
orientation of the ventures. Ernst (2005) concludes that increased FDI inflows had various negative side-effects such as the crowding-out effect between FDI and domestic investment or a high-interest rate policy to attract FDI, detrimental to domestic companies, particularly SMEs.

Similarly, Gold et al. (2017) suggest firms receiving FDls outperform domestic ones in SubSaharan Africa, but the country of origin of the foreign investors is of minor importance, with one exception. MNCs from other African countries use more domestic labour and transfer more technology than their competitors from developed countries. In the case of South Africa, Makhoba and Kaseeram (2019) provide evidence of a significant negative relationship between FDI and employment levels in the South African economy while stating that FDI focuses on more capital-intensive and tends to sacrifice labour-intensive employment opportunities. Interestingly, they suggest a continuation of FDI incentive schemes for the "purpose of improving other macroeconomic developmental objectives that will create job opportunities" (Makhoba \& Kaseeram, 2019, p.119).In Vietnam, the target of a relatively high level of FDI, Anh et al. (2008) find evidence of positive backward technological transfers in the manufacturing sector and positive horizontal spillovers in the service sector. These findings seem to be confirmed by Newman et al. (2015), who report that direct spillovers exist and are more important than indirect ones, suggesting that policies aimed at attracting FDI should be continued. However, according to the authors, the conditions allowing the direct transfer of knowledge between firms need to be improved.

On the other hand - looking primarily at the impact on employment - Jenkins (2006) claims that despite the rapid growth of FDI, the direct employment generated has been very limited in Vietnam. He claims the high productivity in labour-intensive manufacturing or the low valueadd of much of this investment as a prime reason. This is in line with the more recent paper of Nguyen et al. (2020), which shows the adverse effects of FDI on both aggregate employment and skilled labour in Vietnam. Using a large share of M\&As as a mode of entry, foreign investors "might buy Vietnamese firms and cut a large proportion of their personnel. The increasing competition also forces domestic firms to lay off workers. Another reason is limited linkages between domestic and foreign firms which produce minimal spillover effects" (Nguyen et al., 2020, p.56).

In the Indian sub-continent, Rath and Bal (2014) came to the conclusion that FDI "crowds-in" private but not public domestic investment, using a very long time scale (1978-2010). This, however, does imply higher employment. Rizvi and Nishat (2009) compare the impact of FDI on employment opportunities in both India and Pakistan, and China. They suggest that despite other benefits from FDI, this type of investment should not be expected to create direct employment opportunities. The authors recommend other policies, apart from FDI attraction, to stimulate employment growth. On a similar note, Mishra and Palit (2020) found the relationship between FDI and employment "quite convoluted" (p.1488) as the level of employment growth "during the last two decades is quite detectable, but FDI inflows may not be regarded as a major factor for this growth rate" (p.1488). Somehow typically, however, the authors suggest more of the same, i.e. various domestic policy changes to attract more FDI.

It might be surprising, but some authors suggest that outward FDI might also increase employment in the home country (Federico \& Minerva, 2008). When it comes to their theoretical explanation for their empirical findings, they count on FDI inflows rather than outflows in the first two out of three theoretical explanations with fixed local wages and 
equilibrium home employment. The third explanation the authors take from Jones and Kierzkowski (2001). Following FDI outflow, Jones and Kierzkowski (2001) expect countries with a dominance of capital-intensive industries to focus more on labour-intensive industries, thus gaining extra employment. While a legitimate argument, it might be difficult to find this development in the real world.

The standard mainstream economic models often assume FDI to be more productive than home country investment, thus causing both higher GDP and employment (Borensztein et al., 1998; Kosztowniak, 2016). This assumption is the result of a combination of both Keynesian and Neoclassical theories. The Keynesian school offers direct short-term effects in changing domestic production as well as indirect long-term effects from the technological transfer, while Neoclassical models claim that financing capital formation promotes employment and growth (Kida, 2014). Thus, as mentioned above, the overall benefit of FDI to a host country is rarely straightforwardly doubted even by authors of papers who found no relationship, or even reversed causality, for example, when FDI was caused by increases in GDP (for examples of reversed causalities between FDI and GDP and employment, please refer to Kosztowniak, 2016). Although most of the research around the world suggests a negative or weak link between FDI and employment, to the best of our knowledge, no paper suggesting the nature of FDI as a mode of entry might be the cause. The missing relationship was often interpreted as a problem on the part of host countries' economic policies.

\section{Methodology}

Under which conditions can FDI be associated with unemployment? While direct investment might be an important factor for the improvement of economies in a particular stage of development (see, for example, Ozawa's \& Dunning's investment developing path theories, 1992, 1993), FDI in the majority of recipient countries is attracted, or better subsidised using investment incentives (direct and indirect subsidies, ranging from tax cuts to pre-prepared infrastructure).

Firstly, based on basic logic and grain of common sense, the subsidy itself may be proof that the investment would be otherwise (i) smaller, (ii) not be realised, (iii) realised in another country, (iv) realised differently or at a different time (Evan 2010; Evan \& Bolotov 2014). This deduction is based on a longstanding alternative interpretation of the state of affairs of international investment as we know it, which starts with Hymer (1960, 1976). He claimed MNCs must have some sort of non-market advantage to pay for the close to prohibitive costs of production in a very distant and different cultural and socio-economic environment. This is particularly true in the labour market, i.e. when labourers from different cultures are involved and should work together.

Fittingly, cultural differences have risen to prominence as better tools to measure culture exist than at the conception of those theories. Culture has been connected with many aspects of international investment in recent studies, from perceived risk and uncertainty (Mihet, 2013; Outreville, 2018) to corporate governance practices (Daniel et al., 2012) or accounting conservatism (Salter et al., 2013). Cultural categories such as trust are at the core of governance. Wu et al. (2012) used this fact to classify three types of governance environment (rule-based, relationship-based and family-based). They created a model to successfully explain why family-based countries attract relatively more FDI and rule-based countries 
relatively more foreign portfolio investment, a puzzle that could not be explained by more traditional variables such as GDP or trade patterns.

Even without this recent research, the necessity of those non-market advantages of MNCs was accepted and studied further by Kindleberger (1969), Vernon and Wells (1972), Gilpin (1975) and Caves and Caves (1996), among many others, culminating with Dunning (1998, 2001) and his eclectic model of international production including his OLI paradigm (see the discussion below).

Secondly, according to the mainstream comparative static logic presented in Fig. 1, any substantial (i.e. causing sufficient effect) subsidy provided to a direct investor firm (see variables with apostrophe), if compared to the no-subsidy case, will ceteris paribus lead to lower absolute $(\triangle \mathrm{PK}<0)$ and relative prices of capital $(\Delta \mathrm{PK} / \mathrm{w}<0$ i.e. steeper slopes of isocost loci, TCi) causing a different producer optimum (E1'), where labour (L) is substituted with a bigger amount of cheaper capital $(\mathrm{K}$, i.e. the negative substitution effect exceeds the production effect, $|\mathrm{SE}|>|\mathrm{PE}|$, so that $\Delta \mathrm{L} 1<0)$, and a twist in the output expansion path (OEP). The impact on the labour market in the short-run (in the long-run, FDI may cause GDP growth and an increase in employment, see, for example, $\Delta \mathrm{L} 2$, and Okun's law) would be ceteris paribus negative, with a contraction in employment $(\Delta \mathrm{L} 1<0)$ and in the optimum wage $(\Delta \mathrm{w}<0)$ because of a decline in individual demand for labour ( $\mathrm{d}^{\prime} \mathrm{L}<\mathrm{dL}$ ) caused by the FDIrelated subsidy. Provided incentives are offered to the majority of direct investors; this deduction can be extended to the whole industry or the entire economy, depending on the relevance of FDI.

Figure 1 | Impact of FDI-related subsidy on the producer optimum and on the short-run labour demand
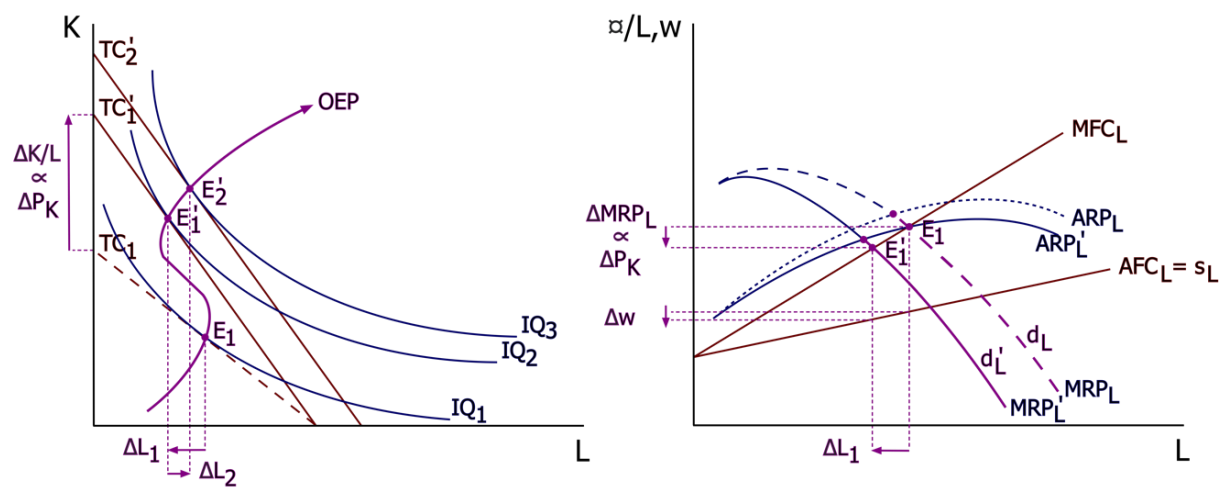

Source: authors

Therefore, we assume that under the existence of FDI-specific subsidies (investment incentives) alternative hypotheses on the relationship between direct investment and employment can be empirically tested on the world level:

(H1) The relationship between FDI and employment is weak or non-existent;

(H2) The relationship between FDI and employment is negative. 
Whether $(\mathrm{H} 1)$ or $(\mathrm{H} 2)$ is true depends, among other things, on the (i) number of countries actively offering investment incentives (the more, the stronger the effect), (ii) the strength of the incentives (the greater the difference $|S E|-|P E|$, the greater the effect), (iii) the origin of FDI (the more supported, the greater the effect), and (iv) the importance of FDI for the economy (the bigger, the greater the effect). Given the existing income heterogeneity and global imbalances, $\mathrm{H} 1$ is a statistically more probable outcome (but we of course also consider the second option and the case that neither hypothesis is valid).

To test the hypotheses, we recur to a dynamic panel model (DPD) in absolute terms

$\Delta L_{t, i}=\Delta L_{t-1, i}+\sum_{l=0}^{k} F D I_{t-l, i}^{I N}$

and in relative terms, taking into account the size and economic level of countries,

$\Delta l_{t, i}=\Delta l_{t-1, i}+\sum_{l=0}^{k} f d i_{t-l, i}^{I N}$

where $\Delta L_{t, i}$ and $\Delta l_{t, i}$ is the change in employment (in persons and percentage points of the total population) and $F D I^{\prime} N_{t, i}$ and $f d i^{\prime} N_{t, i}$ is the inward FDI (in US dollars and percentage points of GDP) for country $i$ and time $t$ (where $/$ is the time lag). The DPDs are estimated with the help of the Blundell-Bond (Blundell \& Bond, 1998) two-step difference generalised method of moments estimator (two-step GMM) with linear moment conditions (Ahn \& Schmidt, 1995), instruments curtailed (collapsed) based on the Roodmand and Kiviet methodology (Kiviet, 2020; Roodman, 2009), and Cragg-Donald over- and under-identification tests (Cragg \& Donald, 1993; Windmeijer, 2018). The number of lags $k$ in the case of FDI is selected with the help of Schwarz information criterion (MMSC-BIC) starting from the middle-run $k=5$.

Our strongly balanced panel dataset is constructed using data from the World Bank, IMF, OECD (for inward FDI and GDP), and GGDC's Penn World Tables 10 (for employment and population) (Feenstra et al., 2015) for 193 countries over the years 1985-2019 (35 years, 6755 observations), inter- and extrapolated with zeros (inward FDI) and cubic splines (change in employment), see Annex 2 for descriptive statistics (including missing values). Inward FDI is defined as net incurrence of liabilities according to BPM6 (labelled FDInetIN and fdinetin in data, change in employment as $\mathrm{dL}$ and $\mathrm{dl}$ ), bilateral data from OECD are grouped by destination (given the scarcity of data on FDI, we do not explore the differences between the World Bank, IMF and OECD's definitions of FDI, assuming them to be nonsignificant). We differentiate between total (net) inward FDI, (net) inward FDI from OECD member countries (varying composition), and net inward FDI from the rest of the world (BRICS, the Middle East etc.).

\section{Results and discussion}

The results of the (robust) two-step Blundell-Bond difference GMM estimation of six models (for total inward FDI aka Model 1, for inward FDI from the OECD aka Model 2, and for inward FDI from the RoW aka Model 3 in both absolute and relative terms) are presented in Tables 1 and 2, post-estimation under- and overestimation LM tests and MMSC information criteria - in Annex 1. Overall, on the significance level of $90 \%$, Models 1-3 seem to be correctly identified (except the under-identification test for Model 1) only for relative terms (dl, fdinetin, fdinetin_oecd, and fdinetin_row) where estimated coefficients are also, on average, more statistically significant (the opposite being true for absolute terms, compare, among others, the number of lags used in both estimated DPDs). This can be explained by the effect of the 
panel countries' size and GDP since the change in employment caused by a small amount of inward direct investment in a big economy and by a big one in a small economy must logically be different. However, even not disregarding the results for absolute terms (which seem to be misidentified and cannot be reasonably improved on $k=5$, at least based on information criteria), the statistical significance of results is (i) overall quite weak (the values of estimated coefficients for inward FDI are all inferior to 0.001 and statistically significant with a p-value of $10 \%$ only for several selected lags, one value even being negative) and (ii) greater for inward FDI from the OECD than for total inward FDI (for relative terms, for inward FDI from the RoW - for absolute terms), which points to a strong validity of ( $\mathrm{H} 1)$ for data at the world level and to a weaker one - for data disaggregated by the direct investor, which, in general, corresponds to our pre-estimation deduction/assumptions.

\subsection{The OLI paradigm}

The general lack of market-oriented drivers of international investment, possibly except access to markets, is increasingly reported (see, for example, Abu Dayeh \& Janíčko, 2021). Our findings suggest that the theoretical case presented in the methodology section is not devoid of logic and that the existence of investment incentives (aka FDI-related subsidies) redirecting investment and changing the relative prices of factors of production may (together with other factors) indeed have a significant negative substitution effect on employment. The effect is strong enough to extinguish any standard positive effects investment has on employment. Many authors have reported the negative relationship from various countries, recipients of FDI, as outlined in the literature review (Ernst, 2005; Jenkins, 2006; Kosztowniak, 2016; Makhoba \& Kaseeram, 2019; Nguyen et al., 2020). In general, a weak (negative) relationship between employment and inward FDI is consistent with the political economy of FDI, specifically the OLI paradigm, which explains the additional advantages of MNCs over local companies with "net ownership", "location", and "internalisation".

The ownership advantage combined with ever-strengthening intellectual property protection (IPP) allows MNCs to monopolise their innovations. While IPP allows MNCs to monopolise proceeds from intellectual property, it also limits free competition and has no positive effects on national economies and the world economy (Evan et al., 2018). From the point of view of MNCs, FDI is the best mode of entry available to block or limit the loss of intellectual property. FDI is designed for the MNC to have more control and allow less technology to diffuse or spillover to local suppliers and competitors than in other modes of entry such as exports or joint ventures. Nevertheless, a great amount of literature relates to finding a link between FDI and technology-based GDP and employment growth in host countries (for a survey of the literature, please, refer for example to, i.e. Clark et al., 2011; Jiang et al., 2018; Xiaoqin Fan ed., 2002). They often find the relationship is rather weak, yet, authors often blame the particularities of the host country rather than FDI. This approach opens them to criticism reversing the logic, i.e. the relationship does not exist unless there is something permissible or particularly favourable on the part of the host government.

The location advantage is the ability of the government to give non-market benefits to MNCs. Those benefits can be regulatory (decreasing ecological standards or labour protection) or financial. Financial benefits are paid from taxes. Current employers are therefore paying their future competitors from their taxes. As the host country's government subsidises MNCs within the concept of investment incentive schemes, it amalgamates the capital available to MNCs 
(up to 35 or even $40 \%$ of the total investment amount in some schemes). It also changes the relative prices among factors of production. The relative price of capital decreases while the relative price of land and, more importantly, labour increases. This extra capital is used to develop more labour-saving techniques.

In contrast to the liberal environment, the current neo-mercantilist state of affairs (Evan \& Bolotov, 2014) in international investment guarantees a higher level of technology and a lower level of employment. We leave the proof of a higher level of taxation, government regulation, and debt due to investment schemes for further research. It can also deduce that the most easily substituted or low-skilled workers will suffer the highest, above market-level unemployment. Again, while they were employed, workers paid for financial incentives to MNCs with their taxes.

The combination of the location advantage and an internationalisation advantage that allows MNCs to optimise benefits from their assets and advantages across countries might be another source of depressed employment. The prime purpose of government subsidies is to redirect FDI from the most suitable investment location to one where the sum of benefits (income) for MNCs is the largest, i.e. the subsidising country. The sub-optimal allocation of the capital where relatively higher saturation of financial markets with capital exists and the returns from such use of capital are smaller allow for smaller economic growth and employment. There is agreement among researchers and practitioners that investment incentive schemes are efficient in attracting FDI (for a survey, please, refer for example, to UNCTAD a global survey of 2020, IGS centre review of best practices 2012). To this end, the OECD even produced a Checklist for Foreign Direct Investment Incentive Policies in 2003 already.

More to the point, UNCTAD reports that above 75 per cent of all countries have improved investment incentive schemes between 2003 and 2019. There is, however, significant confusion caused by the fact that UNCTAD conflates the opposites of liberalisation and promotion of investment schemes. So, some of those countries might liberalise their international investment policies, including cancelling any subsidies.

Table 1 Estimates for absolute values of the DPD model (dL)

\begin{tabular}{|c|c|c|c|}
\hline Variable & Model 1 & Model 2 & Model 3 \\
\hline \multicolumn{4}{|l|}{$\mathrm{dL}$} \\
\hline L1. & $2.832 \mathrm{e}-01$ & $2.445 e-01$ & $3.124 \mathrm{e}-01$ \\
\hline \multicolumn{4}{|l|}{ FDInetIN } \\
\hline.-- & $2.938 \mathrm{e}-06^{*}$ & & \\
\hline L1. & $-2.306 e-07$ & & \\
\hline L2. & $-3.029 e-07$ & & \\
\hline L3. & $-2.391 e-07$ & & \\
\hline L4. & $4.696 \mathrm{e}-07$ & & \\
\hline L5. & $-2.423 e-08$ & & \\
\hline \multicolumn{4}{|l|}{ FDInetIN_OECD } \\
\hline.-- & & $1.214 \mathrm{e}-06$ & \\
\hline
\end{tabular}



L1.
$-2.966 \mathrm{e}-07$
L2.
$-8.896 \mathrm{e}-07$
L3.
$3.485 \mathrm{e}-07$
L4.
5.738e-07
L5.
$1.181 \mathrm{e}-06$

\section{FDInetIN_RoW}

$--$.

L1.

$2.420 \mathrm{e}-06^{\star \star}$

L2.

$8.731 \mathrm{e}-07^{\star * \star}$

L3.

4.744e-07

$-5.107 e-07$

L4.

2.078e-07

L5. $-8.077 \mathrm{e}-07$

_cons

Moment conditions

$1.229 \mathrm{e}-01^{*}$

$1.408 \mathrm{e}-01^{*}$

$1.139 \mathrm{e}-01^{*}$

(linear)

Moment conditions (non-linear)

Number of obs

Number of groups

76

76

76

Obs per group

$\min$

0

0

0

5280

5280

5280

176

176

176

30

30

30

avg

30

30

30

$\max$

30

30

30

Source: authors

Table 2 Estimates for relative values of the DPD model (dl)

\begin{tabular}{|c|c|c|c|}
\hline Variable & Model 1 & Model 2 & Model 3 \\
\hline \multicolumn{4}{|l|}{ dl } \\
\hline L1. & $0.26202365^{*}$ & $0.28268973^{*}$ & $0.27120919^{*}$ \\
\hline \multicolumn{4}{|l|}{ fdinetin } \\
\hline.-- & -0.00015047 & & \\
\hline L1. & $0.00105587^{\star \star *}$ & & \\
\hline L2. & -0.00027568 & & \\
\hline L3. & 0.00003446 & & \\
\hline \multicolumn{4}{|l|}{ fdinetin_oecd } \\
\hline.-- & & 0.00007745 & \\
\hline L1. & & $0.00045229^{*}$ & \\
\hline L2. & & $-0.00086792^{* *}$ & \\
\hline
\end{tabular}




\begin{tabular}{|c|c|c|c|}
\hline \multicolumn{4}{|l|}{ fdinetin_row } \\
\hline.-- & & & -0.00008967 \\
\hline L1. & & & 0.00012951 \\
\hline L2. & & & 0.00064838 \\
\hline L3. & & & 0.00007777 \\
\hline _cons & $0.09130173^{\star *}$ & $0.09107857^{\star \star}$ & $0.09012551^{\star \star}$ \\
\hline $\begin{array}{l}\text { Moment conditions } \\
\text { (linear) }\end{array}$ & 74 & 73 & 74 \\
\hline $\begin{array}{l}\text { Moment conditions } \\
\text { (non-linear) }\end{array}$ & 0 & 0 & 0 \\
\hline Number of obs & 5632 & 5808 & 5632 \\
\hline Number of groups & 176 & 176 & 176 \\
\hline \multicolumn{4}{|l|}{ Obs per group } \\
\hline $\min$ & 32 & 33 & 32 \\
\hline avg & 32 & 33 & 32 \\
\hline $\max$ & 32 & 33 & 32 \\
\hline
\end{tabular}

Source: authors

\section{Conclusion}

This paper is among the first to disentangle the rather complex issue of FDI and employment on a theoretical and econometric level. While using data from 193 countries over the years 1985-2019, we find no significant relationship between FDI inflows and employment. We offer three explanations for our findings. One is aligned with market distribution, and the other two are in opposition to it. First, MNCs enter the country in pursuit of efficiency, cutting the labour cost in purchased assets. Second, the sole purpose of governmental investors' incentive schemes is to redirect FDI from market optimal locations to their respective countries. If successful, world economic growth and employment is decreased as a result. Third, due to extra capital given to MNCs in the form of incentive schemes, the relative price of capital will decrease compared to the relative price of labour, motivating MNCs to use more labour-saving techniques. This might increase FDI and GDP growth while simultaneously decreasing employment in the world economy. Our findings are in line with a large segment of relevant literature. However, we can claim only proof of the absence of a relationship or an insignificant negative relationship between FDI and employment. Future research is needed to confirm the relevance and strength of our theoretical explanations.

\section{References}

Anh, N., Pham, N., Chuc, N., \& Duc, N. (2008). Innovation and Exports in Vietnam's SME Sector. European Journal of Development and Research, 20(2), 262-280. https://doi.org/10.1080/09578810802060801

Ahn, S. C., \& Schmidt, P. (1995). Efficient estimation of models for dynamic panel data. Journal of Econometrics, 68(1), 5-27. https://doi.org/10.1016/0304-4076(94)01641-c 
Blundell, R., \& Bond, S. (1998). Initial conditions and moment restrictions in dynamic panel data models. Journal of Econometrics, 87(1), 115-143. https://doi.org/10.1016/s0304-4076(98)00009-8

Borensztein, E. R., De Gregorio, J. R., \& Lee, J. (1998). How does foreign direct investment affect economic growth? Journal of International Economics, 45(1), 115-135. https://doi.org/10.1016/s0022-1996(97)00033-0

Braconier, H., \& Ekholm, K. (2002). Foreign Direct Investment in Central and Eastern Europe: Employment Effects in the EU. Development Working Papers 161, Centro Studi Luca d'Agliano, University of Milano. https://www.dagliano.unimi.it/media/WP2002_161.pdf

Caves, R. E., \& Caves, R. E. (1996). Multinational Enterprise and Economic Analysis. Cambridge University Press. http://books.google.cz/books?id=1_eNSIA-2WIC\&hl=\&source=gbs_api

Clark, D. P., Highfill, J., de Oliveira Campino, J., \& Rehman, S. S. (2011). FDI, Technology Spillovers, Growth, and Income Inequality: A Selective Survey. Global Economy Journal, 11(2), 1850229. https://doi.org/10.2202/1524-5861.1773

Cragg, J. G., \& Donald, S. G. (1993). Testing Identifiability and Specification in Instrumental Variable Models. Econometric Theory, 9(2), 222-240. https://doi.org/10.1017/S0266466600007519

Cristescu, A., Stanila, L., Popescu, M. E., \& Vasilescu, M. D. (2015). Labour Market Analysis in the Central and Eastern European Countries. Journal of Eastern Europe Research in Business and Economics, Vol. 2015, 12 pages. https://doi.org/10.5171/2015.546201

Daniel, S. J., Cieslewicz, J. K., \& Pourjalali, H. (2012). The Impact of National Economic Culture and Country-Level Institutional Environment on Corporate Practices: Theory and Empirical Evidence. Management International Review, Vol. 52, No. 3, 365-394. https://doi.org/10.1007/s11575-0110108-x

Abu Dayeh, B., \& Janičko, M. (2021). Determinants of Chinese foreign direct investment in central and eastern Europe. Central European Business Review, Vol. 10 (3), 19-36. https://doi.org/10.18267/j.cebr.254

De Castro, P. G., Fernandes, E. A., \& Campos, A. C. (2013). The Determinants of Foreign Direct Investment in Brazil and Mexico: An Empirical Analysis. Procedia Economics and Finance, 2013(5), 231-240. https://doi.org/10.1016/s2212-5671(13)00029-4

Dunning, J. H., \& Narula, R. (1993). Transpacific Direct Investment and the Investment Development Path: The Record Assessed. http://www.merit.unu.edu/publications/rmpdf/1993/rm1993-024.pdf

Dunning, J. H. (1998). Location and the Multinational Enterprise: A Neglected Factor? Journal of International Business Studies, 29(1), 45-66. https://doi.org/10.1057/palgrave.jibs.8490024

Dunning, J. H. (2001). The Eclectic (OLI) Paradigm of International Production: Past, Present and Future. International Journal of the Economics of Business, 8(2), 173-190. https://doi.org/10.1080/13571510110051441

Ernst, C. (2005). The FDI - employment link in a globalising world: The case of Argentina, Brazil and Mexico. Employment Strategy Paper 2005/17, 1-52. https://www.ilo.org/wcmsp5/groups/public/--ed_emp/---emp_elm/documents/publication/wcms_114029.pdf

Estrin, S. (2017). Foreign direct investment and employment in transition economies. Institute for the Study of Labor, Iss. 330. http://dx.doi.org/10.15185/izawol.330

Evan, T. (2010). Some Issues of Political Economics of Multinational Corporations. Acta Oeconomica Pragensia, 18(4), 32-43. https://doi.org/10.18267/j.aop.311 
Evan, T., \& Bolotov, I. (2014). The Weak Relation between Foreign Direct Investment and Corruption: A Theoretical and Econometric Study. Prague Economic Papers, 23(4), 474-492. https://doi.org/10.18267/j.pep.494

Evan, T., Vozárová, P., \& Bolotov, I. (2018). Some Effects of Intellectual Property Protection on National Economies: Theoretical and Econometric Study. Prague Economic Papers, 27(1), 73-91. https://doi.org/10.18267/j.pep.644

Fan, E. X. (2002). Technological Spillovers from Foreign Direct Investment -A Survey. Asian Development Bank, ERD Working Paper No. 33, 1-42. https://www.adb.org/sites/default/files/publication/28326/wp033.pdf

Federico, S., \& Minerva, G. A. (2008). Outward FDI and Local Employment Growth in Italy. Review of World Economics, 144(2), 295-324. https://doi.org/10.1007/s10290-008-0148-x

Feenstra, R. C., Inklaar, R., \& Timmer, M. P. (2015). The Next Generation of the Penn World Table. American Economic Review, 3150-3182. https://www.aeaweb.org/articles?id=10.1257/aer.20130954

Gilpin, R. (1975). US Power and the Multinational Corporation: The Political Economy of Foreign Direct Investment. Basic Books. https://books.google.cz/books/about/U_S_power_and_the_multinational_corporat.html?id=2VO FAAAAIAAJ\&redir_esc $=y$

Gold, R., Görg, H., Hanley, A., \& Seric, A. (2017). South - South FDI: is it really different? Review of World Economics, Vol. 153, No. 4, 657-673. https://doi.org/10.1007/s10290-017-0289-x

Golejewska, A. (2002). Foreign Direct Investment and its Employment Effects in Polish Manufacturing During Transition. Working Papers of Economics of European Integration Division No. 204, 136. http://gnu.univ.gda.pl/ keie/ao4.doc

Hunya, G., \& Geishecker, I. (2005). Employment Effects of Foreign Direct Investment in Central and Eastern Europe. Wiiw Research Report No. 321. https://wiiw.ac.at/employment-effects-offoreign-direct-investment-in-central-and-eastern-europe-dlp-348.pdf

Hymer, S. H. (1976). The International Operations of National Firms: A Study of Direct Foreign $\begin{array}{lllll}\text { Investment } & \text { (2nd } & \text { ed.). } & \text { MIT } & \text { Press }\end{array}$ http://books.google.cz/books?id=7yCxAAAAIAAJ\&hl=\&source=gbs_api

Jenkins, R. O. (2006). Globalisation, FDI and Employment in Viet Nam. Transnational Corporations, 15(1), 115-142. https://digitallibrary.un.org/record/581091/files/iteiit20061_en.pdf

Jiang, L., Zhou, H.-f., Bai, L., \& Zhou, P. (2018). Does foreign direct investment drive environmental degradation in China? An empirical study based on air quality index from a spatial perspective. Journal of Cleaner Production, 176, 864-872. https://doi.org/10.1016/j.jclepro.2017.12.048

Jones, R. W., \& Kierzkowski, H. (2001). A Framework for Fragmentation. In S. W. Arndt \& H. Kierzkowski (Eds.), Fragmentation: New Production Patterns in the World Economy (pp. 17-34). Oxford University Press. https://papers.tinbergen.nl/00056.pdf

Karlsson, A., \& Norden, L. (2007). Home sweet home: Home bias and international diversification among individual investors. Journal of Banking \& Finance, 31(2), 317-333. https://doi.org/10.1016/j.jbankfin.2006.04.005

Kida, N. M. (2014). Foreign Direct Investment Environment and Economic Growth. Acta Universitatis Danubius. $\quad$ CEconomica, 10(4), 31-41. http://journals.univdanubius.ro/index.php/oeconomica/article/view/2384/2642 
Kindleberger, C. P. (1969). American Business Abroad: Six Lectures on Direct Investment. Yale University

Press. https://books.google.cz/books/about/American_Business_Abroad.html?id=1KbyHAAACAAJ\&re dir_esc $=y$

Kiviet, J. F. (2020). Microeconometric dynamic panel data methods: Model specification and selection issues. Econometrics and Statistics, 13, 16-45. https://doi.org/10.1016/j.ecosta.2019.08.003

Kosztowniak, A. (2016). Verification of the relationship between FDI and GDP in Poland. Acta Oeconomica, 66(2), 307-332. https://doi.org/10.1556/032.2016.66.2.6

Lipsey, R. E. (2006). Measuring the Impacts of FDI in Central and Eastern Europe. NBER Working Paper Series, WP 12808. https://doi.org/10.3386/w12808

Makhoba, B. P., \& Kaseeram, I. (2019). The Contribution of Foreign Direct Investment (FDI) To Domestic Employment Levels in South Africa: A Vector Autoregressive Approach. Journal of Economics and Behavioral Studies, 11(1(J), 110-121. https://doi.org/10.22610/jebs.v11i1(j).2752

Mihet, R. (2013). Effects of culture on firm risk-taking: a cross-country and cross-industry analysis. Journal of Cultural Economics, Vol. 37, No. 1, 109-151. https://doi.org/10.1007/s10824-0129186-2

Mishra, R., \& Palit, S. (2020). Role of FDI on Employment Scenario in India. International Journal of Recent Technology and Engineering, Vol. 8, Issue 6, 1481-1489. https://doi.org/10.35940/ijrte.F7777.038620

Newman, C., Rand, J., Talbot, T., \& Tarp, F. (2015). Technology transfers, foreign investment and

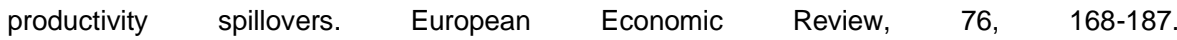
https://doi.org/10.1016/j.euroecorev.2015.02.005

Nguyen, T. Q., Tran, L. T. K., Pham, P. L., \& Nguyen, T. D. (2020). Impacts of Foreign Direct Investment Inflows on Employment in Vietnam. Institutions and Economies, 12/1, 37 -62. https://ijie.um.edu.my/article/view/22022

OECD. (2003). OECD Checklist for Foreign Direct Investment Incentive Policies. https://www.oecd.org/daf/inv/investment-policy/2506900.pdf

Outreville, J. F. (2018). Culture and Life Insurance Ownership: Is It an Issue? Journal of Insurance Issues, Vol. 41, No. 2, 168-192. http://www.insuranceissues.org/PDFs/412O.pdf

Ozawa, T. (1992). Foreign Direct Investment and Economic Development. Transnational Corporations, I(1), 27-54. https://unctad.org/system/files/official-document/iteiitv1n1a3_en.pdf

Radosevic, S., Varblane, U., \& Mickiewicz, T. (2003). Foreign direct investment and its effects on employment in Central Europe. Transnational Corporations, Vol. 12, No. 1, 53-90.

Rath, B. N., \& Bal, D. P. (2014). Do FDI and Public Investment Crowd in Or out Private Investment in India. The Journal of Developing Areas, Vol. 18, No. 3, 269-284. https://doi.org/10.1353/jda.2014.0048

Rizvi, S. Z. A., \& Nishat, M. (2009). The Impact of Foreign Direct Investment on Employment Opportunities: Panel Data Analysis (Empirical Evidence from Pakistan, India and China). The Pakistan Development Review, 48(4II), 841-851. https://doi.org/10.30541/v48i4iipp.841-851

Roodman, D. (2009). A Note on the Theme of Too Many Instruments. Oxford Bulletin of Economics and Statistics, 71(1), 135-158. https://doi.org/10.1111/j.1468-0084.2008.00542.x

Salter, S. B., Kang, T., Gotti, G., \& Doupnik, T. S. (2013). The Role of Social Values and Institutions in Determining Accounting Conservatism. Management International Review, Vol. 53, No. 4, 607633. https://doi.org/10.1007/s11575-012-0152-1 
Tambunan, T. T. H. (2011). Development of small and medium enterprises in a developing country: The Indonesian case. Journal of Enterprising Communities: People and Places in the Global Economy, 5(1), 68-82. https://doi.org/10.1108/17506201111119626

UNCTAD. (2020). World Investment Report 2020. United Nations Publications. https://unctad.org/system/files/official-document/wir2020_en.pdf

Vernon, R. (1972). The Economic Environment of International Business (3rd ed.). Prentice-Hall. http://books.google.cz/books?id=9DQFAQAAIAAJ\&hl=\&source=gbs_api

Windmeijer, F. (2018). Testing Over- and Underidentification in Linear Models, with Applications to Dynamic Panel Data and Asset-Pricing Models. University of Bristol Department of Economics Discussion Paper 18/696, $1-52$. http://www.bristol.ac.uk/efm/media/workingpapers/working_papers/pdffiles/dp18696.pdf

Wu, J., Li, S., \& Selover, D. D. (2012). Foreign Investment vs. Foreign Portfolio Investment, The Effect of the Governance Environment. Management International Review, 52 (5), 643-670.

Zemplinerova, A. (2012). Effects of foreign direct investment: the case of the Czech economy. The Centre for Economic Research and Graduate Education - Economics Institute, Prague, edition 1, number b08. https://www.cerge-ei.cz/pdf/books/zemplinerova_book2.pdf

The research paper passed the review process. | Received: July 10, 2021; Revised: September 5, 2021; Accepted: September 9, 2021; Pre-published online: September 28, 2021; Publised in the regular issue: July 18, 2022. 
\begin{tabular}{l|l} 
Annex 1 & Post-Estimation Tests \\
\hline
\end{tabular}

\begin{tabular}{|c|c|c|c|c|}
\hline \multicolumn{2}{|c|}{$\begin{array}{l}\text { Estimates for absolute values } \\
\text { of the DPD model ( } d L)\end{array}$} & Model 1 & Model 2 & Model 3 \\
\hline \multirow{3}{*}{$\begin{array}{l}\text { Underidentification } \\
\text { test: Cragg-Donald } \\
\text { robust CUE-based } \\
\text { (LM version) }\end{array}$} & Chi-sq df & 69 & 69 & 69 \\
\hline & $p$-value & 0.182 & 0.261 & 0 \\
\hline & J-statistic & 79.496 & 76.089 & 131.58 \\
\hline \multirow{5}{*}{$\begin{array}{l}\text { Overidentification test: } \\
\text { Cragg-Donald robust } \\
\text { CUE-based } \\
\text { (LM version) }\end{array}$} & Chi-sq df & 68 & 68 & 68 \\
\hline & p-value & 0.129 & .171 & 0.178 \\
\hline & J-statistic & 81.321 & 78.948 & 78.612 \\
\hline & Number of groups & 176 & 176 & 176 \\
\hline & Number of obs & 5280 & 5280 & 5280 \\
\hline \multirow{7}{*}{$\begin{array}{l}\text { Andrews-Lu model and } \\
\text { moment selection } \\
\text { criteria }\end{array}$} & Number of groups & 176 & 176 & 176 \\
\hline & J-statistic & 147.964 & 151.274 & 130.247 \\
\hline & Number of moments & 76 & 76 & 76 \\
\hline & Number of parameters & 8 & 8 & 8 \\
\hline & MMSC-AIC & 11.964 & 15.274 & -5.753 \\
\hline & MMSC-BIC & -203.628 & -200.319 & -221.346 \\
\hline & MMSC-HQIC & -77.713 & -74.403 & -95.431 \\
\hline \multicolumn{2}{|c|}{$\begin{array}{l}\text { Estimates for relative values } \\
\text { of the DPD model (dl) }\end{array}$} & Model 1 & Model 2 & Model 3 \\
\hline \multirow{3}{*}{$\begin{array}{l}\text { Underidentification } \\
\text { test: Cragg-Donald } \\
\text { robust CUE-based } \\
\text { (LM version) }\end{array}$} & Chi-sq df & 68 & 69 & 69 \\
\hline & p-value & 0.118 & 0.003 & 0.076 \\
\hline & J-statistic & 82.054 & 106.422 & 86.487 \\
\hline \multirow{5}{*}{$\begin{array}{l}\text { Overidentification test: } \\
\text { Cragg-Donald robust } \\
\text { CUE-based } \\
\text { (LM version) }\end{array}$} & Chi-sq df & 68 & 68 & 68 \\
\hline & p-value & 0.002 & 0.004 & 0.003 \\
\hline & J-statistic & 106.376 & 103.356 & 104.762 \\
\hline & Number of groups & 176 & 176 & 176 \\
\hline & Number of obs & 5632 & 5808 & 5632 \\
\hline \multirow{7}{*}{$\begin{array}{l}\text { Andrews-Lu model and } \\
\text { moment selection } \\
\text { criteria }\end{array}$} & Number of groups & 176 & 176 & 176 \\
\hline & J-statistic & 110.313 & 103.532 & 109.499 \\
\hline & Number of moments & 74 & 73 & 74 \\
\hline & Number of parameters & 6 & 5 & 6 \\
\hline & MMSC-AIC & -25.687 & -32.468 & -26.501 \\
\hline & MMSC-BIC & -241.28 & -248.06 & -242.094 \\
\hline & MMSC-HQIC & -115.365 & -122.145 & -116.179 \\
\hline
\end{tabular}

Source: authors 


\begin{tabular}{lcccccc}
\hline & $\begin{array}{c}\text { Number of } \\
\text { obs }\end{array}$ & Mean & Variance & $\begin{array}{c}\text { Standard } \\
\text { deviation }\end{array}$ & Minimum & Maximum \\
\hline Variables & & & & & & \\
L & 6160 & $1,51 \mathrm{E}+01$ & $4,21 \mathrm{E}+03$ & $6,48 \mathrm{E}+01$ & $-1,06 \mathrm{E}-02$ & $7,99 \mathrm{E}+02$ \\
dL & 5984 & $2,12 \mathrm{E}-01$ & $8,42 \mathrm{E}-01$ & $9,17 \mathrm{E}-01$ & $-5,01 \mathrm{E}+00$ & $2,33 \mathrm{E}+01$ \\
I & 6160 & $3,99 \mathrm{E}+01$ & $9,69 \mathrm{E}+01$ & $9,85 \mathrm{E}+00$ & $4,32 \mathrm{E}+00$ & $1,17 \mathrm{E}+02$ \\
dl & 5984 & $1,19 \mathrm{E}-01$ & $1,14 \mathrm{E}+00$ & $1,07 \mathrm{E}+00$ & $-1,47 \mathrm{E}+01$ & $9,62 \mathrm{E}+00$ \\
FDInetIN & 6755 & $5,97 \mathrm{E}+03$ & $8,12 \mathrm{E}+08$ & $2,85 \mathrm{E}+04$ & $-3,61 \mathrm{E}+05$ & $7,34 \mathrm{E}+05$ \\
FDInetIN_OECD & 6755 & $3,60 \mathrm{E}+03$ & $3,90 \mathrm{E}+08$ & $1,97 \mathrm{E}+04$ & $-1,96 \mathrm{E}+05$ & $4,54 \mathrm{E}+05$ \\
FDInetIN_RoW & 6755 & $2,39 \mathrm{E}+03$ & $3,80 \mathrm{E}+08$ & $1,95 \mathrm{E}+04$ & $-3,84 \mathrm{E}+05$ & $3,69 \mathrm{E}+05$ \\
fdinetin & 6755 & $5,02 \mathrm{E}+00$ & $1,34 \mathrm{E}+03$ & $3,66 \mathrm{E}+01$ & $-5,83 \mathrm{E}+01$ & $1,70 \mathrm{E}+03$ \\
fdinetin_oecd & 6755 & $3,36 \mathrm{E}+00$ & $2,65 \mathrm{E}+03$ & $5,15 \mathrm{E}+01$ & $-1,81 \mathrm{E}+03$ & $1,21 \mathrm{E}+03$ \\
fdinetin_row & 6755 & $1,81 \mathrm{E}+00$ & $2,33 \mathrm{E}+03$ & $4,82 \mathrm{E}+01$ & $-1,10 \mathrm{E}+03$ & $1,81 \mathrm{E}+03$
\end{tabular}

\section{Dimensions}

iso3

ABW AFG AGO ALB ARE ARG ARM ATG AUS AUT AZE BDI BEL BEN BFA BGD BGR BHR BHS BIH BLR BLZ BMU BOL BRA BRB BRN BTN BWA CAF CAN CHE CHL CHN CIV CMR COD COG COL COM CPV CRI CUW CYM CYP CZE DEU DJI DMA DNK DOM DZA ECU EGY ERI ESP EST ETH FIN FJI FRA FSM GAB GBR GEO GHA GIN GMB GNB GNQ GRC GRD GTM GUY HKG HND HRV HTI HUN IDN IND IRL IRN IRQ ISL ISR ITA JAM JOR JPN KAZ KEN KGZ KHM KIR KNA KOR KWT LAO LBN LBR LBY LCA LKA LSO LTU LUX LVA MAC MAR MDA MDG MDV MEX MHL MKD MLI MLT MMR MNE MNG MOZ MRT MUS MWI MYS NAM NER NGA NIC NLD NOR NPL NRU NZL OMN PAK PAN PER PHL PLW PNG POL PRT PRY PSE QAT RUS RWA SAU SDN SEN SGP SLB SLE SLV SRB SSD STP SUR SVK SVN SWE SWZ SXM SYC TCA TCD TGO THA TJK TKM TLS TON TTO TUN TUR TUV TZA UGA UKR URY USA UZB VCT VEN VNM VUT WSM YEM ZAF ZMB ZWE

year

1985-2019

\begin{tabular}{|c|c|c|c|}
\hline $\begin{array}{c}\text { Number of missing } \\
\text { values }\end{array}$ & Frequency & Percentage & Cumulated percentage \\
\hline 0 & 5,983 & 88.57 & 88.57 \\
\hline 1 & 1 & 0.01 & 88.59 \\
\hline 2 & 176 & 2.61 & 91.19 \\
\hline 4 & 35 & 0.52 & 91.71 \\
\hline 5 & 560 & 8.29 & 100.00 \\
\hline & 6,755 & 100.00 & \\
\hline
\end{tabular}

Source: authors 